\title{
A rare bladder cancer - small cell carcinoma: review and update
}

\author{
Nabil Ismaili
}

\begin{abstract}
Small cell carcinoma of the bladder (SCCB) is rare, highly aggressive and diagnosed mainly at advanced stages. Hematuria is the main symptom of this malignancy. The origin of the disease is unknown; however the multipotent stem cell theory applies best to this case. Histology and immunohistochemistry shows a tumour which is indistinguishable from small cell lung carcinoma (SCLC). Coexistence of SCCB with other types of carcinoma is common. The staging system used is the TNM-staging of bladder transitional cell carcinoma. The treatment is extrapolated from that of SCLC. However, many patients with SCCB undergo radical resection which is rarely performed in SCLC. Patients with surgically resectable disease $(<$ or $=$ CT1-4aNOMO) should be managed with multimodal therapy associating chemotherapy, surgery and/or radiotherapy. Neoadjuvant chemotherapy using four chemotherapy cycles followed by radical cystectomy is the most effective therapeutic sequence. Patients with unresectable disease ( $>$ or $=c T 4 b N+M+$ ) should be managed with palliative chemotherapy based on neuroendocrine type regimens comprising a platinum drug (cisplatin in fit patients). The prognosis of the disease is poor mainly in the case of pure small cell carcinoma. Other research programs are needed to improve the outcome of SCCB.
\end{abstract}

\section{Disease name}

Small cell carcinoma of the bladder

Poorly differentiated neuroendocrine carcinoma of the bladder

\section{Definition}

Small cell carcinoma of the bladder (SCCB) is a rare, poorly differentiated neuroendocrine epithelial tumour associated with a more aggressive behaviour and poorer outcome than bladder transitional cell carcinoma (TCC). It is mostly diagnosed at advanced stage and generally believed to have a high metastatic potential. Current knowledge of this disease is limited and was based mainly on retrospective investigations. The disease was initially described in 1981 by Cramer et al [1]. Bladder small cell carcinoma (SCC) is frequently found combined with other histological forms of bladder cancer: TCC, adenocarcinoma and squamous cell carcinoma [2-10]. The pathogenesis of primary SCCB is unknown. However, several hypotheses were proposed to explain the origin of SCC in the bladder. The most important

Correspondence: ismailinabil@yahoo.fr

Medical oncology, centre régional d'oncologie, Agadir, Morocco hypothesis was: the origin of SCCB may be a multipotential common stem cell. Treatment of SCCB is extrapolated from the treatment of small cell lung carcinoma (SCLC). This comprehensive review would provide a real insight into the epidemiology, pathogenesis, diagnosis, staging, treatment, and prognosis of SCCB.

\section{Literature review}

We based our review on the MEDLINE database using the key words 'bladder cancer', 'small cell carcinoma', 'pathogenesis', 'diagnosis', 'treatment', and 'prognosis'. The research was performed since January 1980 up to July 2011. Only one prospective phase II study was reported in the English literature. Twenty retrospectives studies including $\geq 20$ patients have been reported. There have also been several interesting case reports and literature reviews.

\section{Review}

\section{I - Epidemiology}

Small cell cancer of the bladder is an extremely rare bladder malignancy with a mean frequency of $0.7 \%$ and a range between $0.35 \%$ and $1.8 \%$ [2-7]. The reported incidence is less than 1-9/1,000,000 habitant. Since 
1980, less than 1000 cases of SCCB have been diagnosed and reported in the literature up to July 2011. The demographic characteristics of SCCB are similar to those seen in patients with transitional cell carcinoma (TCC). The majority of patients are male, with a mean sex ratio equal to $5: 1$, and a range between $1: 1$ to $16: 1$ [2-8,10-15]. Most patients are in the sixth to seventh decade. Mean age at time of first diagnosis is 67 years; ranging between 32 to 91 years $[5,8,11,12]$. Like TCC, SCCB is often associated with a smoking history (in 65 to $79 \%$ of the cases) $[4,7-9]$. White patients represent the vast majority of cases ( $74 \%$ to $97 \%$ of cases) $[5,9,12]$. Table 1 summarizes the epidemiological and clinical characteristics of SCCB.

\section{II - Pathogenesis}

Pathogenesis of SCCB is not well defined. However, several hypotheses were proposed to explain the origin of $\mathrm{SCC}$ in the bladder. The most important hypotheses were: 1. malignant transformation of bladder neuroendocrine cells gives rise to bladder SCC. This hypothesis was supported by the fact that neuroendocrine cells were found previously in the urinary bladder [16]; 2 . SCCB arises from urothelial metaplastic changes $[1,17]$; and a third and more powerful theory suggests that the origin of SCCB may be a multipotential common stem cell that has the ability to differentiate into various cell types depending on the influence of specific transformation or progression-related gene. This may explain the

Table 1 Demographics and clinical characteristics of patients with SCCB

\begin{tabular}{|c|c|c|c|c|c|c|c|c|}
\hline Authors & No & $\begin{array}{l}\text { Sex } \\
\text { ratio }\end{array}$ & $\begin{array}{c}\text { Age } \\
\text { (range) }\end{array}$ & $\begin{array}{l}\text { Smoking } \\
\text { history } \\
(\%)\end{array}$ & $\begin{array}{l}\text { White } \\
\text { race } \\
(\%)\end{array}$ & Symptoms (\%) & $\begin{array}{l}\text { Frequency } \\
\text { of SCC (\%) }\end{array}$ & $\begin{array}{l}\text { Percentage } \\
\text { of mixed } \\
\text { histology }\end{array}$ \\
\hline $\begin{array}{l}\text { Blomjous } 1989 \\
\text { [2] }\end{array}$ & 18 & $2.6: 1$ & $\begin{array}{c}69(50- \\
81)\end{array}$ & - & - & Hematuria; Dysuria & $0.48 \%$ & $55.6 \%$ \\
\hline $\begin{array}{l}\text { Holmang } 1995 \\
\text { [3] }\end{array}$ & 25 & $2.5: 1$ & $\begin{array}{c}71.2 \\
(54-87)\end{array}$ & - & - & Hematuria & $0.7 \%$ & $60 \%$ \\
\hline $\begin{array}{l}\text { Lohrisch } 1999 \\
\text { [4] }\end{array}$ & 14 & $1: 1$ & - & $79 \%$ & - & Hematuria (100\%); Local pain (36\%) & $0.35 \%$ & $50 \%$ \\
\hline $\begin{array}{l}\text { lczkowski } 1999 \\
\text { [11] }\end{array}$ & 46 & $6.7: 1$ & $\begin{array}{c}67(32- \\
91))\end{array}$ & - & - & - & - & - \\
\hline $\begin{array}{l}\text { Siefker-Radtke } \\
2004 \text { (MD } \\
\text { Anderson)[12] }\end{array}$ & 88 & $3.3: 1$ & $\begin{array}{c}68(31- \\
87)\end{array}$ & - & $88 \%$ & Hematuria & - & $79.5 \%$ \\
\hline Cheng 2004[8] & 64 & $3.3: 1$ & $\begin{array}{c}66(36- \\
35)\end{array}$ & $65 \%$ & - & Hematuria (88\%) & - & $68 \%$ \\
\hline $\begin{array}{l}\text { Mangar } 2004 \\
{[14]}\end{array}$ & 14 & $6: 1$ & $\begin{array}{c}74(54- \\
91) \\
\end{array}$ & - & - & Hematuria (93\%) & - & - \\
\hline $\begin{array}{l}\text { Choong } 2005 \\
{[5]} \\
\text { (Mayo Clinic) }\end{array}$ & 44 & $3: 1$ & $\begin{array}{c}66.9 \\
(47-88)\end{array}$ & - & $97.7 \%$ & $\begin{array}{l}\text { Hematuria (68.2\%); Incidental finding (18\%); Urinary } \\
\text { obstruction (6.8\%); Dysuria (2.3\%); Abdominal pain (2.3\%); } \\
\text { Urinary tract infection (2.3\%); Ectopic ACTH secretion (2.3\%) }\end{array}$ & $0.5 \%$ & $38.6 \%$ \\
\hline $\begin{array}{l}\text { Abrahams } 2005 \\
\text { [9] }\end{array}$ & 51 & $4: 1$ & $\begin{array}{c}67(39- \\
87)\end{array}$ & - & $74 \%$ & $\begin{array}{c}\text { Haematuria (63\%); Dysuria (12\%); Abdominal pain (2\%); } \\
\text { Urinary obstruction (2\%); Weight loss (2\%); Urinary tract } \\
\text { infection (2\%) }\end{array}$ & - & $88 \%$ \\
\hline Bex 2005[10] & 25 & $11.5: 1$ & $\begin{array}{l}64(40- \\
90)\end{array}$ & - & - & - & - & $44 \%$ \\
\hline Quek 2005[6] & 25 & $3: 1$ & $\begin{array}{c}68(40- \\
82)\end{array}$ & - & - & - & $1 \%$ & $30 \%$ \\
\hline $\begin{array}{l}\text { Mukesh } 2008 \\
\text { [13] }\end{array}$ & 20 & $3: 1$ & 68 & - & - & - & - & - \\
\hline Ismaili 2008[7] & 14 & $16: 1$ & $\begin{array}{c}60.5 \\
(45-78)\end{array}$ & $78.5 \%$ & - & - & $1.8 \%$ & $64.3 \%$ \\
\hline Bex 2009[15] & 17 & $16: 1$ & $\begin{array}{c}62(44- \\
78) \\
\end{array}$ & - & - & - & - & $50 \%$ \\
\hline $\begin{array}{l}\text { Siefker-Radtke } \\
2009 \text { (MD } \\
\text { Anderson)[33] }\end{array}$ & 30 & $14: 2$ & $\begin{array}{c}66.2 \\
(43.1- \\
81)\end{array}$ & - & - & - & - & $43 \%$ \\
\hline Bex 2010[40] & 51 & $4.1: 1$ & $\begin{array}{c}65(57- \\
74)\end{array}$ & - & - & - & - & $59 \%$ \\
\hline
\end{tabular}


coexistence of SCCB with TCC, and the heterogeneity of the immunohistochemical staining (cytokeratin and endocrine markers) [18-20].

\section{III - Clinical features}

The clinical features of SCCB are similar to those of bladder TCC and reflect the presence of a tumoral mass. Gross hematuria is the most common symptom in SCCB which was noted in 63 to $88 \%$ of the cases $[5,8,9,12]$. Dysuria has been reported as the second most common symptom [2,9]. Urinary obstruction, abdominal pain, urinary tract infection and weigh loss have been reported occasionally $[4,5,9]$. Rare cases of paraneoplastic syndromes such as ectopic ACTH secretion and hypercalcaemia were also reported [5,21].

\section{IV - Diagnosis}

Diagnosis of SCCB is mainly accomplished via histopathological examination of specimens obtained by cystoscopy and transurethral resection of the bladder tumour (TURBT) [22]. Immunochemistry staining is extremely helpful in establishing the diagnosis. The role of molecular biology has not yet been defined.

\section{(A) Histopathology}

In histological studies, SCCB are identical to SCLC. Therefore, the diagnosis is based on the criteria established by the WHO classification system (2004), used for the diagnosis of SCLC. In light microscopy, morphological studies of SCCB sections stained with haematoxylin and eosin showed packed cells having scant cytoplasm containing few organelles. Tumour is composed of nests of small round malignant cells with pyknotic round to oval nuclei and evenly dispersed "salt and pepper chromatin" (Figure 1A, B and 1C) [9]. The mitotic rate is high (> 10 mitotic figures / 10 high-power fields) in $57 \%$ of the cases. Tumour rosettes were seen in $23.5 \%$ of the cases. Tumour necrosis was present in the majority of the cases. Crush artefact (Azzopardi effect) was found in $78.4 \%$ of the cases. Vascular invasion was present in $16.7 \%$ of the cases [9]. In most reports, the authors showed a higher incidence of mixed SCC $[2-10,15]$. In Abrahams study, mixtures of SCC

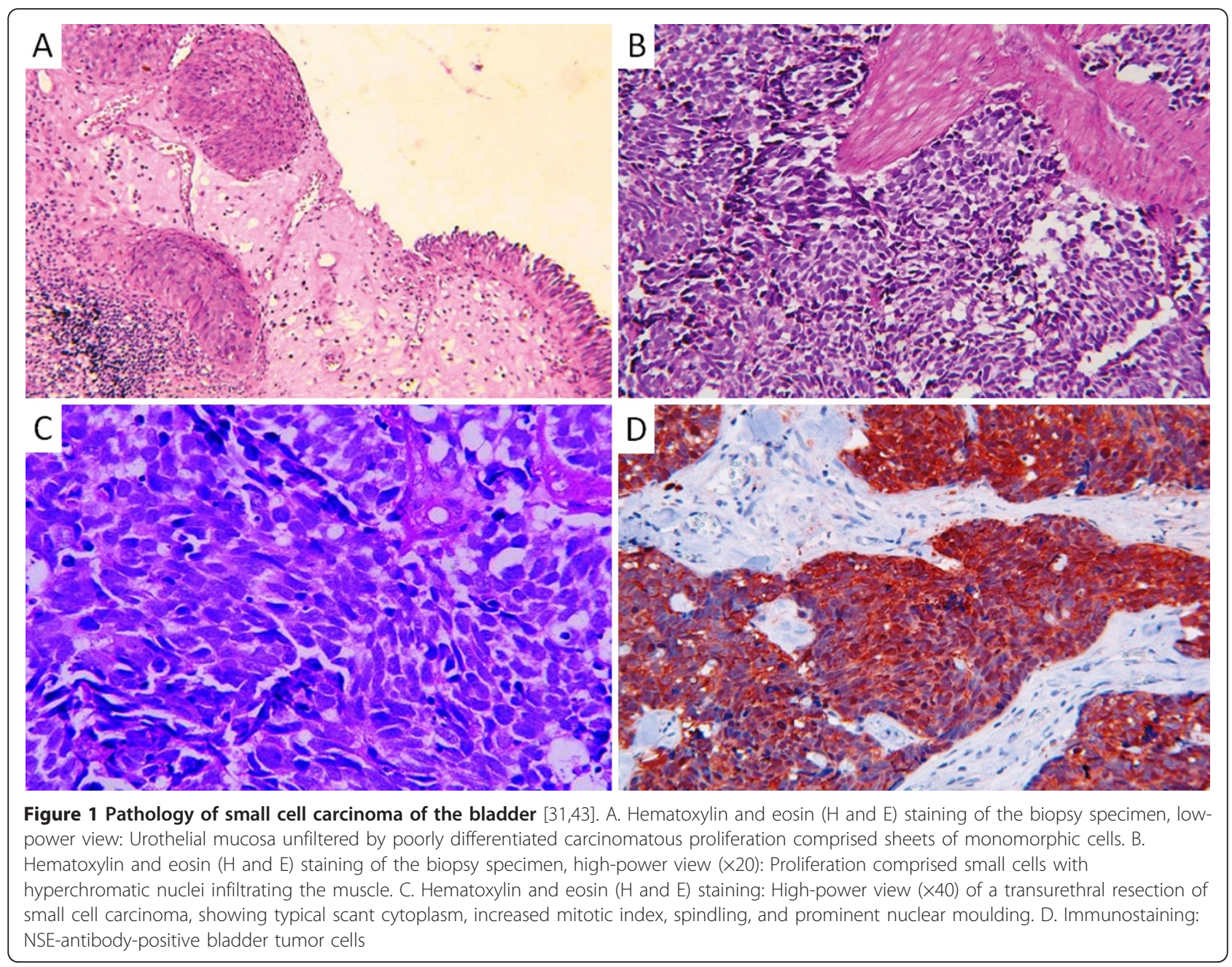


with transitional cell carcinoma was present in $70 \%$ of the cases, while mixtures of SCC with adenocarcinoma and squamous carcinoma were present only in $8 \%$ and $10 \%$ of the cases respectively [9].

\section{(B) Immunohistochemistry}

Immunohistochemistry has a central role for the diagnosis of SCCB through the staining of tumour components by antibody markers targeting the following antigens: neuron-specific enolase (NSE), chromogranin, synaptophysin, serotonin, cytokeratin, S-100 protein, TTF1, EGFR and C-KIT (table 2) [2,9,11,23-28]. The most expressed markers would result on an intense staining of the cytoplasm: NSE (with a frequency of 88.5\%) (Figure 1D), synaptophysin (72.4\%), and chromogranin $(50 \%)[2,9,11,23]$. SCCB are also stained with the epithelial markers: CAM 5.2, CK7, and EMA in 59\%, 41\%, and $77.7 \%$ of the cases, respectively. This supports the urothelial origin of SCCB $[2,9,11,24]$. TTF-1 expression in SCCB was found in $40 \%$ of the tumours in 2 studies, demonstrating that this marker can be expressed in SCC other than those of pulmonary origin [24,25]. Immunochemistry staining of EGFR and C-KIT showed weak cytoplasmic staining in $30 \%$ and $27 \%$ of the cases, respectively $[9,26,27]$. PDGFRA expression was reported in one case [28].

Table 2 Immunohistochemistry findings in small cell carcinoma of the urinary bladder.

\begin{tabular}{|c|c|c|}
\hline Antibody & $\begin{array}{l}\text { No of } \\
\text { studies }\end{array}$ & $\begin{array}{l}\% \text { of positives staining } \\
\text { (mean) }\end{array}$ \\
\hline \multicolumn{3}{|c|}{ Neuroendocrine markers } \\
\hline NSE[2,9,11,23] & 4 & $25-100 \%(88.5 \%)$ \\
\hline Synaptophysin[2,11,9] & 3 & $66.6-76 \%(72.4 \%)$ \\
\hline Serotonin[23] & 1 & $78 \%$ \\
\hline $\begin{array}{l}\text { Chromogranin } \\
{[2,9,11,17]}\end{array}$ & 4 & $22-89 \%(50 \%)$ \\
\hline \multicolumn{3}{|l|}{ Epithelial markers } \\
\hline Cytokeratin[2,23] & 2 & $70-77 \%(75 \%)$ \\
\hline $\mathrm{EMA}[2]$ & 1 & $77.7 \%$ \\
\hline CK7[24] & 1 & $59 \%$ \\
\hline CAM 5.2[2,11,9] & 3 & $47-66.6 \%(41 \%)$ \\
\hline \multicolumn{3}{|l|}{ Other markers } \\
\hline S-100 protein[23] & 1 & $40 \%$ \\
\hline TTF1[24,25] & 2 & $39-50 \%(40 \%)$ \\
\hline EGFR[9,26] & 2 & $27-36 \%(28.6 \%)$ \\
\hline$\underline{\text { C-KIT[9,27] }}$ & 2 & $22-27 \%(27 \%)$ \\
\hline CD44v6[11] & 1 & $7 \%$ \\
\hline PDGFR[28] & 1 case report & + \\
\hline
\end{tabular}

Abbreviations. NSE = neuron specific enolase; $E M A$ = epithelial membrane antigen; CK7 = cytokeratine 7; EGFR = epidermal growth factor receptor; PDGFR = platelet derived growth factor

\section{(C) Molecular genetics}

Genetic alterations in SCCB have been the subject of few studies, because of the rarity of the disease. A Comparative genomic hybridization (CGH) study has demonstrated chromosomal deletions at $10 \mathrm{q}, 4 \mathrm{q}, 5 \mathrm{q}$ and $13 \mathrm{q}$ $[18,29]$. These regions are frequently deleted in human tumours and known to carry some tumour suppressor genes: PTEN located at 10q23 and the retinoblastoma gene located at 13q14 [30]. Additions of DNA sequences have been reported at 5p, 6p, 8q and 20q [18,29]. However, no clear single genetic lesion has been characterized. Other studies are necessary to define the role of molecular genetics in the diagnosis of SCCB.

\section{V - Bladder small cell cancer imaging}

As for TCC of the bladder, the most widely used imaging examination of SCCB is the pelvic computed tomography scan of the bladder mass and the locoregional extension (bladder wall and pelvic lymph nodes).

\section{VI - Staging}

In most cases, the diagnosis is made at advanced stages (T3-T4/N+/M+) (Figure 2A) [31]. More than 95\% of SCCB cases are diagnosed at muscle invasive stage T2 or more $[5-9,11,12]$. As an example, in a large MD Anderson series of 88 cases, only $4.5 \%$ (4 patients) were diagnosed at superficial stage of the disease $(\mathrm{Ta} / \mathrm{T} 1)$, while $40.1 \%(n=36)$ were diagnosed at stage $T 2,28.3 \%$ ( $\mathrm{n}=25)$ were diagnosed at stage T3-T4a (stage III) and $26.1 \%(\mathrm{n}=23)$ were diagnosed at stage $\mathrm{T} 4 \mathrm{~b}-\mathrm{M}+$ (stage IV) [12]. Similar findings were observed in three others larges series $[5,8,11]$. As for bladder TCC, the TNM-staging system was commonly used for SCCB $[2,3,5-8,14,12,32,33]$. Patients with SCCB restricted to the bladder, should be considered as having surgically resectable disease ( $\leq \mathrm{T} 1-4 \mathrm{aN} 0 \mathrm{M} 0)$ [33]. In this case, treatment with neoadjuvant chemotheapy followed by surgery is favored. Patients with regional or non regional lymph nodes (retroperitoneal lymph nodes or distant lymph nodes) or with distant metastasis have the disease at advanced stage (surgically unresectable disease) $(\geq \mathrm{cT} 4 \mathrm{bN}+\mathrm{M}+)$ [33]. Systemic chemotherapy is the treatment of choice for these patients.

Based on two large studies, the most frequent sites of metastasis were pelvic and retroperitoneal lymph nodes (28.6\% - 53\%), liver (23.8\% - 47\%) (Figure 2B), bone (23.8 - 33\%), brain (7.9\% - 16\%) and lung (9.5\% - 13\%) $[5,12]$. Consequently, the staging of SCCB should include computed tomography scan of the pelvis, abdomen chest, brain, and bone scan.

\section{VII - Differential diagnosis}

SCCB must be differentiated from several other cancers [23]: 


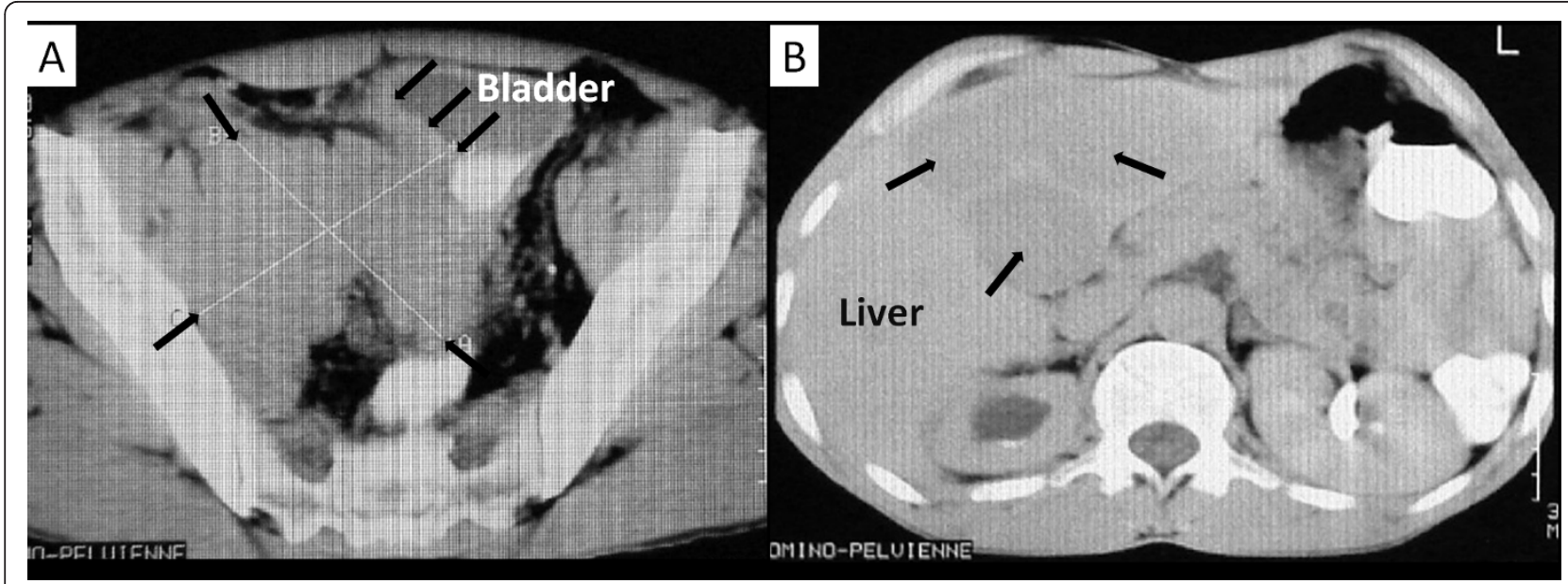

Figure 2 Bladder small cell carcinoma imaging [31]. A. Computed tomography scan of the pelvis shows a heavy tumor at the right bladder wall with intraluminal and extravesical extension (arrows). B. Computed tomography scan of the abdomen shows a multinodular liver disease from bladder small cell carcinoma (arrows).

"Direct invasion of the bladder by SCC of the prostate; prostatic small cell carcinoma is typically negative for prostate-specific antigen.

*Metastatic SCC from another source, usually from the lung. Metastatic SCLC may not be distinguishable histologically from a primary SCCB; however, the presence of TCC component (including TCC in situ) would support a diagnosis of bladder SCC.

"Primary lymphomas of the bladder; lymphomas are positive for leukocyte common antigen (LCA), and negative for keratin and neuroendocrine markers.

\section{VIII - Disease management}

Because of the rarity of $\mathrm{SCCB}$, there is no standard treatment of the disease. SCCB is an aggressive tumour (90\% of patients are at stage II or more and $25 \%$ are at stage IV). This favours the use of chemotherapy (CT) in the management of the disease [12]. Table 3 summarizes the most important studies addressing the management of SCCB.

\section{(A)Radical resection}

In contrast with SCLC, more than half of the patients with SCCB undergo radical resection $[3,5-8,12]$. In a review of 88 cases, reported by MD Anderson Cancer Centre, 46 patients undergone cystecomy [12]. Similarly in two other studies, the radical resection was performed in 60 to $70 \%$ of the cases $[5,8]$. Surgery was favoured because of the frequent combination of SCC with TCC. In fact, in one study, $60 \%$ of the patients having SCCB developed TCC, 24 to 26 months after the completion of curative chemo-radiotherapy (CRT) [4]. However, in a multi-institutional review of 64 patients with localised SCCB, the efficacy of cystectomy has been questioned as no survival difference was found between patients undergoing surgery and those without surgery (5-year survival was $16 \%$ vs. $18 \%$, respectively) [8]. Surgery alone is not appropriate to achieve cure for patients with SCCB. In the retrospective study conducted by MD Anderson, the patients who received neoadjuvant CT have significantly better survival than those who did not receive neoadjuvant $\mathrm{CT}$ [12].

\section{(B)Radiotherapy}

In general, SCLC is treated with a combination of radiotherapy (RT) and CT. In analogy to SCLC, RT either alone or in combination with $\mathrm{CT}$, was used to treat SCCB at localised disease [3,4,10,15,32].

Three retrospectives studies with longer follow-up (5 years), have assessed the role of curative RT in the management of localised bladder SCC $[3,4,15]$. In the first study $(\mathrm{n}=25)$, a group of 18 patients received surgery and curative radiotherapy (without chemotherapy) [3]. In the 2 others studies, 10 and 17 patients, respectively, received sequential chemo-radiotherapy $[3,4]$. The 5 years survival was equal to $28 \%$, in the first study, vs. $70 \%$ and $36 \%$ in the second and third studies, respectively $[3,4,15]$. Long-term survivors have been reported (up to 18 years) [3], however, those with longer followup suggest a higher likelihood of relapse over time [4]. These results confirmed that radiotherapy can be curative, but significantly more curative when used in combination with chemotherapy.

\section{(C) Chemotherapy}

Chemotherapy is the major treatment modality for SCCB $[34,35]$. In one large series, the authors showed on multivariate analysis that cisplatin chemotherapy is the only predictor factor for survival of SCCB patients $(p<0.0001)$ [35]. In surgically resectable disease chemotherapy is used as neoadjuvant therapy to shrink the 
Table 3 Treatment strategies and outcome of bladder small cell carcinoma according to the most important studies published in the English literature.

\begin{tabular}{|c|c|c|c|c|c|c|}
\hline \multirow{3}{*}{$\begin{array}{l}\text { Authors } \\
\text { Blomjous } 1989 \text { [2] }\end{array}$} & \multirow{3}{*}{$\begin{array}{l}\text { No } \\
18\end{array}$} & \multirow{3}{*}{$\begin{array}{l}\begin{array}{l}\text { Study } \\
\text { design }\end{array} \\
\text { Retrospective }\end{array}$} & \multirow{3}{*}{$\begin{array}{l}\text { Stages (No) } \\
\text { T2(5) } \\
\text { T3(8) } \\
\text { T4(5) }\end{array}$} & \multicolumn{2}{|c|}{ Treatments (No) } & \multirow{3}{*}{$\begin{array}{l}\text { Results and comments } \\
\text {-OS and } 2 \text { years survival in the whole group = } 9 \text { months } \\
\text { and } 27.7 \% \text { respectively } \\
\text {-OS and Survival at } 2 \text { years in CT group vs. no CT group } \\
=\text { NR vs. } 7 \text { months and } 60 \% \text { vs. } 15.5 \% \text {, respectively }\end{array}$} \\
\hline & & & & $\begin{array}{l}\mathrm{CT} \\
\text { group }\end{array}$ & $\begin{array}{c}\text { TURBT } \rightarrow \text { RT } \rightarrow \text { CT } \\
\text { TURBT } \\
\rightarrow C T(1) \\
R C \rightarrow C T(1) \\
C T \rightarrow R C(1)\end{array}$ & \\
\hline & & & & $\begin{array}{l}\text { Non-CT } \\
\text { group }\end{array}$ & $\begin{array}{c}\text { TURBT } \rightarrow \text { RT(9) } \\
\text { RC(3) } \\
\text { None(1) }\end{array}$ & \\
\hline Holmang 1995 [3] & 25 & Retrospective & $\begin{array}{l}\mathrm{T} 2(7) \\
\mathrm{T} 3(10) \\
\mathrm{T} 4(2) \\
\mathrm{IVM}+(6)\end{array}$ & & $\begin{array}{l}\mathrm{C} \rightarrow \mathrm{RT}(18) \\
\mathrm{CT}(2) \\
\text { None(5) }\end{array}$ & 5 years survival in the whole group $=20 \%$ \\
\hline \multirow[t]{2}{*}{ Lohrisch 1999 [4] } & 14 & Retrospective & $\begin{array}{l}\mathrm{LD}(9) \\
\mathrm{ED}(1)\end{array}$ & $\begin{array}{c}\mathrm{CT} \\
\text { group }\end{array}$ & $\begin{array}{l}\mathrm{CT} \rightarrow \mathrm{RT}(8) \\
\mathrm{CT} \rightarrow \mathrm{RC}(1) \\
\mathrm{CT} \rightarrow \mathrm{C}(1)\end{array}$ & $\begin{array}{c}\text {-OS in the CT grope }=41 \text { months } \\
\text {-Survival at } 5 \text { years }=70 \% \text { in the } C T \text { group vs. } 0 \% \text { in the } \\
\text { non CT group }\end{array}$ \\
\hline & & & $\mathrm{LD}(2) ; \mathrm{ED}(2)$ & $\begin{array}{l}\text { Non-CT } \\
\text { group }\end{array}$ & $\begin{array}{c}\text { RT(2) } \\
\text { None(2) }\end{array}$ & \\
\hline Bastus 1999 [32] & 5 & Retrospective & $\begin{array}{l}\text { T2(1) } \\
\text { T3(3) } \\
\text { T3N1(1) }\end{array}$ & & $\mathrm{T} \rightarrow \mathrm{RT}(5)$ & $\begin{array}{l}\text {-All patients were treated with sequential chemo- } \\
\text { radiotherapy; } \\
-2 \text { years survival in the whole group }=80 \%\end{array}$ \\
\hline \multirow[t]{2}{*}{$\begin{array}{l}\text { Siefker-Radtke 2004 } \\
\text { (MD Anderson) [12] }\end{array}$} & 46 & $\begin{array}{l}\text { Retrospective } \\
\text { cohort }\end{array}$ & $\begin{array}{l}\mathrm{T} 2(13) \\
\mathrm{T} 3-\mathrm{T} 4 \mathrm{a}(8) \\
\end{array}$ & & $\mathrm{T} \rightarrow \mathrm{RC}(21)$ & $\begin{array}{l}5 \text { years survival in neoadjuvant CT group was significantly } \\
\text { better than surgery alone group }=78 \% \text { vs. } 36 \%, p=0.026\end{array}$ \\
\hline & & & $\begin{array}{l}\text { T2(12) } \\
\text { T3-T4a(7) } \\
\text { Unknown }(n=6)\end{array}$ & & $\mathrm{RC}(25)$ & \\
\hline Cheng 2004 [8] & 64 & $\begin{array}{l}\text { Retrospective } \\
\text { cohort }\end{array}$ & $\begin{array}{l}\mathrm{T} 1(1) \\
\mathrm{T} 2(30) \\
\mathrm{T} 3(29) \\
\mathrm{T} 4(4)\end{array}$ & & $\begin{array}{l}\mathrm{RC}(38) \\
\mathrm{RT}(10) \\
\mathrm{CT}(23)\end{array}$ & $\begin{array}{l}\text { No difference in survival between } R C \text { group vs. non-RC } \\
\text { group }\end{array}$ \\
\hline \multirow[t]{2}{*}{ Mangar 2004 [14] } & 14 & Retrospective & $\begin{array}{l}\mathrm{T} 3(8) \\
\mathrm{T} 3 \mathrm{~N} 1(1) \\
\mathrm{T} 4(2) \\
\mathrm{IVM}+(3)\end{array}$ & $\begin{array}{l}\mathrm{RC} \\
\text { group }\end{array}$ & $\begin{array}{c}\mathrm{RC} \rightarrow \mathrm{CT} \rightarrow \mathrm{RT}(1) \\
\mathrm{RC} \rightarrow \mathrm{RT}(3) \\
\mathrm{RC}(2)\end{array}$ & Outcome in RC group > outcome in non-RC group \\
\hline & & & & $\begin{array}{l}\text { Non-RC } \\
\text { group }\end{array}$ & $\begin{array}{l}\text { PRT(5) } \\
\text { None(3) }\end{array}$ & \\
\hline \multirow[t]{3}{*}{$\begin{array}{l}\text { Choong } 2005 \\
\text { (Mayo Clinic) [5] }\end{array}$} & 44 & Retrospective & $\|(12)$ & & $\begin{array}{l}\mathrm{RC}(7) \\
\mathrm{CT} \rightarrow \mathrm{RC}(1) \\
\mathrm{PC}(3)\end{array}$ & $\begin{array}{c}-5 \text { years survival in the whole group }=25 \% \\
-5 \text { years survival in stage } \mathrm{II}>\mathrm{III} / \mathrm{IV}=63 \%, 15 \% \text {, and } 10 \% \\
\text { respectively, } p<0.001 ; \\
\text {-No difference between stages } \mathrm{III} \text { and IV }\end{array}$ \\
\hline & & & $\|(13)$ & & $\begin{array}{l}\mathrm{RC}(8) \\
\mathrm{RC} \rightarrow \mathrm{CT}(2)\end{array}$ & \\
\hline & & & $\mathrm{IV}(19)$ & & $\begin{array}{l}\mathrm{C} \rightarrow \mathrm{CT}(10) \\
\mathrm{RC}(2) \\
\mathrm{CT}(5)\end{array}$ & \\
\hline \multirow[t]{2}{*}{ Bex 2005 [10] } & 25 & Prospective & $\begin{array}{l}\mathrm{LD}(10) \\
\mathrm{ED}(3)\end{array}$ & $\begin{array}{c}\mathrm{CT} \\
\text { group }\end{array}$ & $\mathrm{CT}(13) \rightarrow \mathrm{RT}(8)$ & $C T>$ non-CT (OS $=15$ vs. 4 months respectively, $p=$ \\
\hline & & & $\begin{array}{l}\mathrm{LD}(7) \\
\mathrm{ED}(5)\end{array}$ & $\begin{array}{l}\text { Non-CT } \\
\text { group }\end{array}$ & $\begin{array}{l}\mathrm{RT}(5) \\
\mathrm{RC}(3) \\
\mathrm{P}(4)\end{array}$ & \\
\hline Quek 2005 [6] & 25 & Retrospective & $\begin{array}{l}/ / I(4) \\
\| I(2) \\
\text { IV N+ or } \mathrm{M}+(19)\end{array}$ & & $\begin{array}{l}\rightarrow A C T(13) \\
C T \rightarrow R C(1) \\
R C(11)\end{array}$ & $\begin{array}{c}\text {-Survival in mixed SCCB }>\text { survival in pure SCCB, } p=0.06 \\
-R C+A C T>R C \text { alone }\end{array}$ \\
\hline \multirow[t]{2}{*}{ Mukesh 2008 [13] } & 20 & Retrospective & $\mathrm{LD}(11) ; \mathrm{ED}(9)$ & $\begin{array}{l}\text { CT } \\
\text { group } \\
(13)\end{array}$ & $\begin{array}{l}\mathrm{CT} \rightarrow \mathrm{RT}(6) \\
\mathrm{RC} \rightarrow \mathrm{CT}(7)\end{array}$ & $\begin{array}{c}\text { Outcome in CT group > outcome in non-CT (OS }=33 \\
\text { months vs. } 3 \text { months, respectively) }\end{array}$ \\
\hline & & & & $\begin{array}{l}\text { Non-CT } \\
\text { group } \\
(7)\end{array}$ & $\begin{array}{l}\mathrm{BSC}(4) \\
\mathrm{RC}(4) \\
\mathrm{RT}(1)\end{array}$ & \\
\hline
\end{tabular}


Table 3 Treatment strategies and outcome of bladder small cell carcinoma according to the most important studies published in the English literature. (Continued)

\begin{tabular}{|c|c|c|c|c|c|}
\hline Ismaili 2008 [7] & 14 & Retrospective & $\begin{array}{l}\|(4) \\
\| I(5) \\
\operatorname{IVMO}(5)\end{array}$ & $\begin{array}{c}\mathrm{RC} \rightarrow \mathrm{CT}(4) \\
\mathrm{RC}(5) \\
\mathrm{CT} \rightarrow \mathrm{RC}(2) \\
\mathrm{CT}(1) \\
\mathrm{RCT}(1) \\
\text { None }(1)\end{array}$ & $\begin{array}{c}\text {-Survival in mixed SCCB }>\text { survival in pure SCCB, } p=0.01 \\
-C T+\text { Surgery }>\text { Surgery }\end{array}$ \\
\hline Bex 2009 [15] & 17 & Retrospective & $\begin{array}{l}\mathrm{LD}(17): \\
-\mathrm{T} 2(14) \\
-\mathrm{T} 3(2) \\
-\mathrm{T} 4 \mathrm{a}(1)\end{array}$ & $\begin{aligned} C T \rightarrow & R T \text { (60: } 56-70 G y)(17) \\
& \text { Salvage RC (3) }\end{aligned}$ & $\begin{array}{l}\text {-All patients have been treated with sequential } \\
\text { chemoradiotherapy } \\
- \text { OS }=32.5 \text { months } \\
\begin{array}{c}-2,3 \text {, and } 5 \text { years survival }=56 \%, 47 \% \text {, and } 36 \% \\
\text { respectively }\end{array}\end{array}$ \\
\hline \multirow[t]{2}{*}{$\begin{array}{l}\text { Siefker-Radtke } 2009 \\
\text { (MD Anderson) [33] }\end{array}$} & 30 & Phase II & $\begin{array}{l}\text { Resecable patients } \\
\text { (18): T2N0M0 }\end{array}$ & $\mathrm{CT} \rightarrow \mathrm{RC}$ & $\begin{array}{c}-5 \text { years survival in operable group }=80 \% \\
\text {-OS }=58 \text { months vs } 13.3 \text { months, in operable vs non } \\
\text { operable patients, respectively } \\
\text {-Incidence of brain metastasis in stage III/IV }=50 \%\end{array}$ \\
\hline & & & $\begin{array}{l}\text { Unresecable } \\
\text { patients(12): T3b- } \\
\text { 4aN0M0 }\end{array}$ & CT alone & \\
\hline \multirow[t]{2}{*}{ Bex 2010 [40] } & 51 & Retrospective & LD(39) & $\mathrm{CT} \rightarrow \mathrm{RT}$ & $\begin{array}{l}\text {-Survival of patients with } L D=35 \text { months vs } 6 \text { months in } \\
\text { patients with } E D \text {. } \\
\text {-Incidence of brain metastasis }=10.5 \%\end{array}$ \\
\hline & & & $\mathrm{ED}(12)$ & $\mathrm{CT}$ & \\
\hline
\end{tabular}

Abbreviations. OS = overall survival; $\mathrm{NS}=$ no significant; $\mathrm{RC}=$ radical cystectomy; TURBT $=$ transurethral resection of the bladder tumour; $\mathrm{ACT}=$ adjuvant chemotherapy; $\mathrm{NCT}=$ neoadjuvant chemotherapy; $\mathrm{PC}=$ partial cystectomy; $\mathrm{CT}=$ chemotherapy; $\mathrm{RCT}=$ concurrent chemoradiotherapy; $\mathrm{PRT}=$ palliative radiotherapy; NR = no reached; $L D$ = limited disease; ED = extensive disease; SCCB = small cell carcinoma of the bladder; Definition for LD (limited disease): in analogy to SCLC, patient with any local stage, no distant metastases and involvement of maximally one loco regional lymph node less than $2 \mathrm{~cm}$ in imaging (cTx cN0-1 M0) [15]; Definition for ED (extensive disease): unresectable and metastatic disease [15].

tumour prior to local therapy or as adjuvant treatment after surgical resection [5,12].

Neoadjuvant chemotherapy Neoadjuvant CT before surgery in surgically resectable SCCB has been investigated in several retrospective studies and in one phase II prospective study $[12,33]$. In addition primary CT was used in sequence with radiation to increase the efficacy of RT $[4,10,15,32]$.

Neoadjuvant CT in bladder SCC cancer has four theoretical advantages [36,37]:

*the early treatment of micrometastatic disease,

*the systemic treatment is better tolerated by allowing the preoperative administration of CT drugs in optimal doses with less toxicity,

*SCCB is highly chemosensitive disease; the vast majority of patients have great responses,

*downstaging, which facilitates the surgical techniques.

One retrospective cohort study and one phase II clinical trial demonstrated the advantage of $\mathrm{CT}$ in neoadjuvant setting.

In the MD Anderson retrospective study, 46 operable patients were included; the first group of patient ( $\mathrm{n}=$ 21) was treated with 4 cycles of neoadjuvant sequential CT regimen based on ifosfamide plus doxorubicin at day 1 repeated every 42 days and etoposide plus cisplatin at day 21 repeated every 42 days; the second group was treated with surgery alone $(n=25)$. At last follow-up, 5-year survival was significantly higher in CT group: $78 \%$ versus $36 \%$ in surgery alone group ( $p=$ 0.026) [12]. In addition, the results of the MD Anderson phase II clinical trial recently published, confirmed theses results. In this prospective study, 30 eligible patients were included, eighteen of them were surgically resectable and 12 were surgically unresectable. Operable patients have been treated with neoadjuvant CT followed by surgery. At last follow-up, OS and 5 years survival in resectable group was equal to 58 months and $80 \%$, respectively [33].

Based on these data, neoadjuvant CT should be considered as the treatment of choice of surgically resectable SCCB.

Adjuvant chemotherapy No clear data defines the role of adjuvant CT after primary surgery of invasive bladder SCC. Only one retrospective study conducted by the University of Southern California has addressed this question. In the published article, the authors concluded that adjuvant CT may provide improved survival compared with cystectomy alone [6]. In addition, the Mayo Clinic recommendations propose cystectomy alone for patients with stage II disease, and adjuvant chemotherapy for patients with stage III and VI (M0) disease [5]. However, it is important to note that many institutions who followed the Mayo recommendations of initial 
cystectomy report very poor outcomes and high likelihood of upstaging $[5,6]$.

Chemotherapy in advanced disease When SCCB arise outside the bladder, CT plays a prominent role in the management of these tumors. In metastatic setting, the most commonly used regimen for SCCB is cisplatin plus etoposide CT in analogy to SCLC $[5,12,15]$. Etoposide is administered at 100 to $120 \mathrm{mg} / \mathrm{m}^{2}$ intravenously on day 1 to 3 , repeated every 3 weeks. Cisplatin is usually given at 70 to $100 \mathrm{mg} / \mathrm{m}^{2}$ intravenously on day 1 . The MD Anderson group showed that preoperative CT with a neuroendocrine regimen was more likely to successfully eradicate the small cell component compared to regimens typically used for TCC. In fact, of the 12 patients treated with a neuroendocrine regimen only 2 had small cell carcinoma present at cystectomy. However, for those 9 patients treated with a transitional cell carcinoma regimen (MVAC) 6 had small cell carcinoma still present at cystectomy [12]. Consequently, this group recommended the protocols used in the neuroendocrine tumours containing etoposide and cisplatin or ifosfamide and doxorubicin for both histological types: pure SCC and mixed SCC [38]. Other authors recommended a regimen covering both small cell component and TCC component for mixed SCCB: the addition of taxane or ifosfamide to the standard platinum plus etoposide regimen may be considered [39]. In the unfit patient, cisplatin should be substituted with carboplatin.

Other chemotherapy regimens including etoposide-cisplatine alternating protocol either with ifosfamide-doxorubicin or with cyclophosphamide, doxorubicin and vincristin (CAV), as well as single agents, including paclitaxel, irinotecan, topotecan, and doxorubicin, have all been used in SCCB $[5,12]$. Table 4 summarizes the most used regimen in the management of SCCB.

\section{(D) Nervous system and bone metastasis}

Based on the high efficacy of chemotherapy against metastatic small cell carcinoma, palliative radiotherapy is rarely adopted. However, radiotherapy is reserved for treatment of symptomatic brain metastases, symptomatic bone metastases and cord compression. According to a recent retrospective investigation, the incidence of symptomatic brain metastases from SCCB is significantly lower than that from SCLC. Therefore, the authors do not recommend systematic prophylactic brain irradiation (PCI) in patients with SCCB [40]. In another hand, the authors at MD Anderson, report in the phase II clinical trial a $50 \%$ incidence of brain

Table 4 Chemotherapy regimens used in the treatment of SCCB

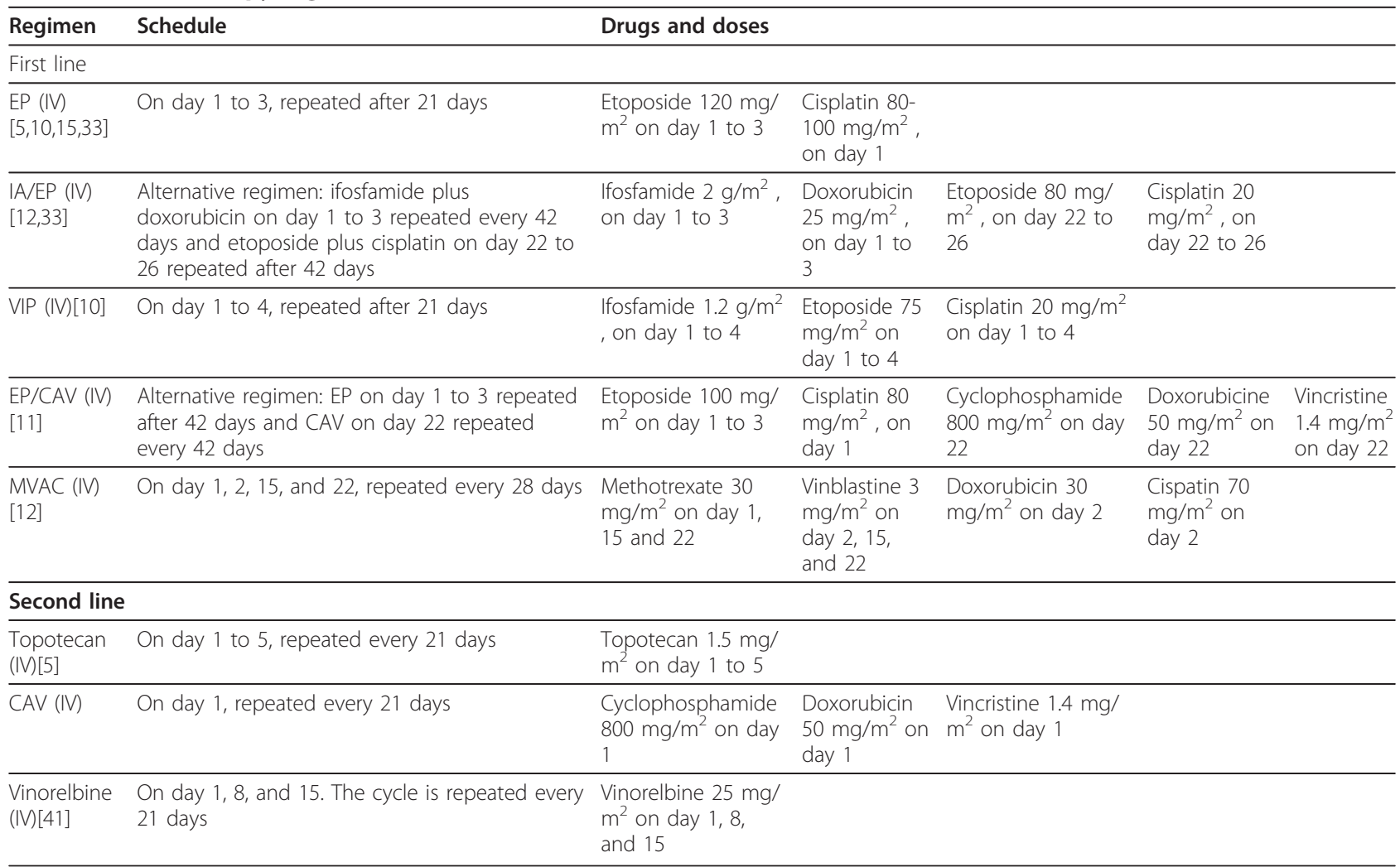


metastases in patients with stage III-IV disease; this information suggests a possible group to consider for PCI [33].

\section{(E) Progressive or relapsing disease}

In analogy to SCLC, the likelihood of response to further CT can be predicted on the basis of the response to previous therapy and the duration of free interval. Patients who did not respond to previous therapy or who relapsed within 3 months are judged refractory. For patients with sensitive disease, the same induction regimen can be used for treatment. Three weekly vinorelbine has been tested in a case series and has showed an interesting activity [41]. Second-line regimens are summarized in table 4.

(F) Future directions

Despite the promising results obtained by chemotherapy based on cisplatin, the majority of patients die of metastatic disease.
The progress in molecular biology has led to the investigation of new molecules in several primary tumours including SCLC. Overexpression of several receptors such as the VEGFR (vascular endothelial growth factor receptor) on endothelial cells, the EGFR (epidermal growth factor receptor, the c-KIT, the PDGFR (platelet derived growth factor receptor) and the FGFR (fibroblast growth factor receptor), on tumor cells has prompted the scientific community to evaluate the efficacy and safety of new molecules targeting signaling pathways controlled by these proteins in metastatic SCLC (bevacizumab, sunitinib, sorafenib, pazopanib, Imatinib, cetuximab, erlotinib, Gefitinib, lapatinib, everolimus, bortezomib) (Figure 3). According to preliminary studies, targeting angiogenesis would be the most promising strategy [42]. In analogy to SCLC, the role of theses molecules in metastatic SCCB should be defined in the future.

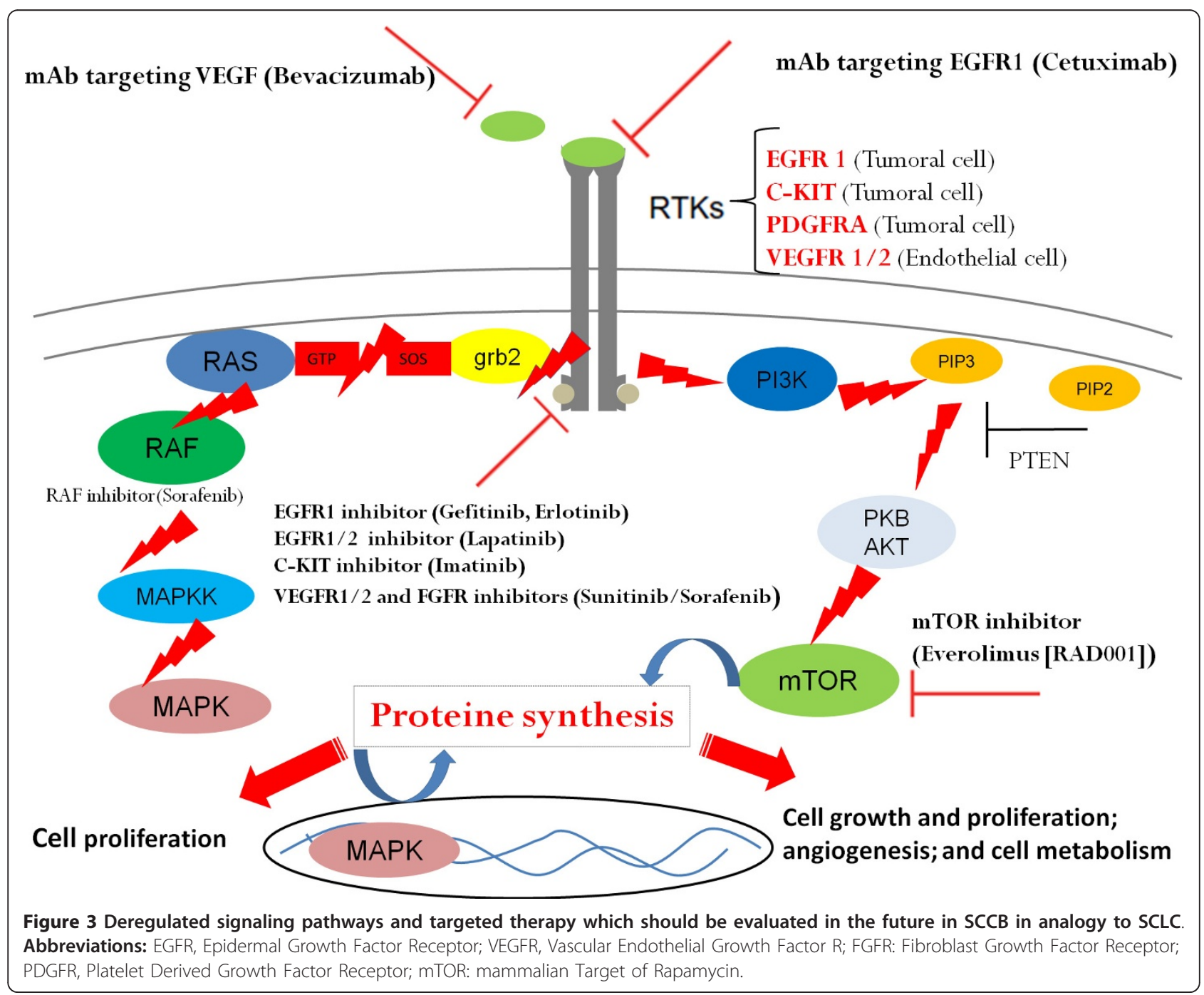




\section{IX-Treatment recommendations [39,43-45]}

\section{(A) Surgically resectable disease}

Neoadjuvant chemotherapy followed by radical resection should be considered as the treatment of choice in surgically resectable SCCB. This sequence can achieve a cure in $78-80 \%$ of the patients [12,33];

Sequential chemo-radiotherapy is a second treatment option which can achieve a cure in 36 to $70 \%$ of the cases $[4,15]$;

In the case when surgery was performed first, adjuvant chemotherapy or adjuvant chemo-radiotherapy should be indicated [5,6];

\section{(B) Advanced disease}

In advanced stages, chemotherapy based on cisplatin should be considered as the treatment of choice for patients with good performance status (0-1) and good renal function-Glomerular filtration rate $($ GFR $)>60$ $\mathrm{mL} / \mathrm{min}$. The treatment should be based on neuroendocrine regimens type etoposide plus cisplatin or the sequential protocol; ifosfamide plus doxorubicin at day 1 and etoposide plus cisplatin at day 21 (table 4). In unfit patients, cisplatin should be substituted by carboplatin AUC 5 to 6.

\section{$X$-Prognosis}

The prognosis of SCCB is poor. Five-year survival rate of all stages combined is equal to $19 \%$ (16 to $25 \%$ ) [5,8]. Based on one large study, the 5-year survival rates for patients with Stage II, III, and IV were 63.6\%, 15.4\%, and $10.5 \%$ respectively. Advanced stages III and IV have poorer outcome than stage II disease; $P<0.0001$ [5]. In addition, according to 2 series, pure small cell histology was shown to have poorer outcome than the mixed small cell histology $[6,7,34]$. Because of the rarity of this disease, no others prognostic factors were identified.

\section{XI-Conclusions}

Primary SCCB is a rare and aggressive tumour. In more than $50 \%$ of the cases, the diagnosis is performed at advanced stages III/IV. Demographic and clinical features are comparable to those of bladder TCC. The origin of disease is not clearly defined; but the multipotent theory is the most accepted. Criteria of pathological diagnosis and radiological work-up are similar to those of SCLC. Coexistence of SCCB with other types of carcinoma is common. Immunochemistry plays a major role in the diagnosis using the markers of neuroendocrine tumours. The staging system mostly used is the TNM-staging system of bladder TCC. The best treatment for this tumour was not established for certain; only one prospective study was published up to now. The strategy of therapy was extrapolated from SCLC. In surgically resectable disease, the management should include multimodal therapy with chemotherapy first followed by radical resection or radical radiotherapy. In advanced disease, chemotherapy using platinum agent (cisplatin in fit patients) is the mainstay treatment. The prognosis of SCCB is poor. Pure small cell histology shows to have worsened prognosis than the mixed small cell histology. Further investigations are needed to improve our knowledge in the diagnosis and treatment of this rare disease.

\section{Abbreviations}

AD: advanced disease; CAM 5.2: cytokeratin marker; CAV: cyclophosphamide, doxorubicin and vincristin; CGH: comparative genomic hybridization; CK7: cytokeratin 7; CT: chemotherapy; EGFR: epidermal growth factor receptor; CKIT: Proto-Oncogene encoding a transmembrane protein-kinase; EMA: epithelial membrane antigen; LD: localised disease; MVAC: methotrexat, vimblastin, doxorubicin and cisplatin; PTEN: Phosphatase and Tensin Homolog; RT: radiotherapy; SCC: small cell carcinoma; SCCB: small cell carcinoma of the bladder; SCLC: small cell lung cancer; TCC: transitional cell carcinoma; TTF1: thyroid transcription factor 1; TURBT: transurethral resection of the bladder tumour.

\section{Acknowledgements}

We sincerely thank Mohammed Ismaili, Professor of Microbiology from Moulay Ismail University, Meknes, Morocco.

We sincerely thank Samia Arifi, Medical Oncologist from the department of Medical Oncology, Hassan II Hospital, Fes, Morocoo

\section{Authors' contributions}

$\mathrm{NI}$ is involved in concept design, in data collection, drafting and critically revising the manuscript.

\section{Competing interests}

The author declares that they have no competing interests.

Received: 10 August 2011 Accepted: 13 November 2011

Published: 13 November 2011

\section{References}

1. Cramer SF, Aikawa M, Cebelin M: Neurosecretory granules in small cell invasive carcinoma of the urinary bladder. Cancer 1981, 47(4):724-30.

2. Blomjous CEM, Vos W, De Voogt HJ, van der Valk P, Meijer CJLM: Small cell carcinoma of the urinary bladder. A clinicopathologic, morphologic, immunohistochemical and ultrastructural study of 18 cases. Cancer 1989, 64(6):1347-57.

3. Holmang S, Borghede G, Johansson SL: Primary small cell carcinoma of the bladder: a report of 25 cases. J Urol 1995, 153(6):1820-2.

4. Lohrisch C, Murray N, Pickles T, Sullivan L: Small cell carcinoma of the bladder: Long term outcome with integrated chemoradiation. Cancer 1999, 86(11):2346-52

5. Choong NW, Quevedo JF, Kaur JS: Small cell carcinoma of the urinary bladder. The Mayo Clinic experience. Cancer 2005, 103(6):1172-8.

6. Quek ML, Nichols PW, Yamzon J, Daneshmand S, Miranda G, Cai J, Groshen S, Stein JP, Skinner DG: Radical cystectomy for primary neuroendocrine tumors of the bladder: the university of southern California experience. J Urol 2005, 174(1):93-6.

7. Ismaili N, Elkarak F, Heudel PE, Flechon A, Droz JP: Small cell cancer of the bladder: The Leon-Berard cancer centre experience. Indian J Urol 2008, 24:494-497.

8. Cheng L, Pan CX, Yang XJ, Lopez-Beltran A, MacLennan GT, Lin H, Kuzel TM, Papavero V, Tretiakova M, Nigro K, Koch MO, Eble JN: Small cell carcinoma of the urinary bladder: A clinicopathologic analysis of 64 patients. Cancer 2004, 101(5):957-62.

9. Abrahams NA, Moran C, Reyes AO, Siefker-Radtke A, Ayala AG: Small cell carcinoma of the bladder: a contemporary clinicopathological study of 51 cases. Histopathology 2005, 46(1):57-63.

10. Bex A, Nieuwenhuijzen JA, Kerst M, Pos F, van Boven H, Meinhardt W, Horenblas S: Small cell carcinoma of bladder: a single-center prospective study of 25 cases treated in analogy to small cell lung cancer. Urology 2005, 65(2):295-9. 
11. Iczkowski KA, Shanks JH, Allsbrook WC, Lopez-Beltran A, Pantazis CG, Collins TR, Wetherington RW, Bostwick DG: Small cell carcinoma of urinary bladder is differentiated from urothelial carcinoma by chromogranin expression, absence of CD44 variant 6 expression, a unique pattern of cytokeratin expression, and more intense gamma-enolase expression. Histopathology 1999, 35(2):150-6.

12. Siefker-Radtke AO, Dinney CP, Abrahams NA, Moran C, Shen Y, Pisters LL, Grossman HB, Swanson DA, Millikan RE: Evidence supporting preoperative chemotherapy for small cell carcinoma of the bladder: a retrospective review of the M. D. Anderson cancer experience. J Urol 2004, 172(2):481-4

13. Mukesh M, Cook N, Hollingdale AE, Ainsworth NL, Russell SG: Small cell carcinoma of the urinary bladder: a 15-year retrospective review of treatment and survival in the Anglian Cancer Network. BJU Int 2009, 103(6):747-52.

14. Mangar SA, Logue JP, Shanks JH, Cooper RA, Cowan RA, Wylie JP: Smallcell carcinoma of the urinary bladder: 10-year experience. Clin Oncol ( $R$ Coll Radiol) 2004, 16(8):523-7.

15. Bex A, de Vries R, Pos F, Kerst M, Horenblas S: Long-term survival after sequential chemoradiation for limited disease small cell carcinoma of the bladder. World J Urol 2009, 27(1):101-6.

16. Ali SZ, Reuter VE, Zakowski MF: Small cell neuroendocrine carcinoma of the urinary bladder: a clinicopathologic study with emphasis on cytologic features. Cancer 1997, 79:356-361.

17. Oesterling JE, Brendler CB, Burgers JK, Marshall FF, Epstein Jl: Advanced small cell carcinoma of the bladder. Successful treatment with combined radical cystoprostatectomy and adjuvant methotrexate, vinblastine, doxorubicin, and cisplatin chemotherapy. Cancer 1990, 65(9):1928-36.

18. Terracciano L, Richter J, Tornillo L, Beffa L, Diener PA, Maurer R, Gasser TC, Moch H, Mihatsch MJ, Sauter G: Chromosomal imbalances in small cell carcinomas of the urinary bladder. J Pathol 1999, 189(2):230-5.

19. Christopher ME, Seftel AD, Sorenson K, Resnick MI: Small cell carcinoma of the genitourinary tract: an immunohistochemical, electron microscopic and clinicopathological study. J Urol 1991, 146(2):382-8.

20. van Hoeven KH, Artymyshyn RL: Cytology of small cell carcinoma of the urinary bladder. Diagn Cytopathol 1996, 14(4):292-7.

21. Reyes CV, Soneru I: Small cell carcinoma of the urinary bladder with hypercalcemia. Cancer 1985, 56(10):2530-3.

22. Sved P, Gomez P, Manoharan M, Civantos F, Soloway MS: Small cell carcinoma of the bladder. BJU Int 2004, 94(1):12-7.

23. Grignon DJ, Ro JY, Ayala AG, Shum DT, Ordóñez NG, Logothetis CJ, Johnson DE, Mackay B: Small cell carcinoma of the urinary bladder. A clinicopathologic analysis of 22 cases. Cancer 1992, 69(2):527-36.

24. Jones TD, Kernek KM, Yang XJ, Lopez-Beltran A, MacLennan GT, Eble JN, Lin H, Pan CX, Tretiakova M, Baldridge LA, Cheng L: Thyroid transcription factor 1 expression in small cell carcinoma of the urinary bladder: an immunohistochemical profile of 44 cases. Hum Pathol 2005, 36(7):718-23.

25. Agoff SN, Lamps LW, Philip AT, Amin MB, Schmidt RA, True LD, Folpe AL: Thyroid transcription factor- 1 is expressed in extrapulmonary small cell carcinomas but not in other extrapulmonary neuroendocrine tumors. Mod Pathol 2000, 13(3):238-42.

26. Wang X, Zhang S, MacLennan GT, Eble JN, Lopez-Beltran A, Yang XJ, Pan CX, Zhou H, Montironi R, Cheng L: Epidermal growth factor receptor protein expression and gene amplification in small cell carcinoma of the urinary bladder. Clin Cancer Res 2007, 13(3):953-7.

27. Pan CX, Yang XJ, Lopez-Beltran A, MacLennan GT, Eble JN, Koch MO, Jones TD, Lin H, Nigro K, Papavero V, Tretiakova M, Cheng L: c-kit Expression in small cell carcinoma of the urinary bladder: prognostic and therapeutic implications. Mod Pathol 2005, 18(3):320-3.

28. Terada T: Autopsy case of primary small cell carcinoma of the urinary bladder: KIT and PDGFRA expression and mutations. Pathol Int 2009, 59(4):247-50.

29. Léonard C, Huret JL, Gfco; Groupe français, de cytogénétique oncologique: From cytogenetics to cytogenomics of bladder cancers. Bull Cancer 2002, 89(2):166-73.

30. Church DN, Bahl A: Clinical review - small cell carcinoma of the bladder. Cancer Treat Rev 2006, 32(8):588-93.

31. Ismaili N, Ghanem S, Mellas N, Afqir S, Taleb M, Amrani M, Gamra L, Errihani H: Small cell carcinoma of the urinary bladder: a case report and review of the literature. J Cancer Res Ther 2009, 5(2):133-6.
32. Bastús R, Caballero JM, González G, Borrat P, Casalots J, Gomez de Segura G, Martí LI, Ristol J, Cirera L: Small cell carcinoma of the urinary bladder treated with chemotherapy and radiotherapy: Results in five cases. Eur Urol 1999, 35(4):323-6.

33. Siefker-Radtke AO, Kamat AM, Grossman HB, Williams DL, Qiao W, Thall PF, Dinney CP, Millikan RE: Phase II clinical trial of neoadjuvant alternating doublet chemotherapy with ifosfamide/doxorubicin and etoposide/ cisplatin in small-cell urothelial cancer. J Clin Oncol 2009, 27(16):2592-7.

34. Ismaili N, Heudel PE, Elkarak F, Kaikani W, Bajard A, Ismaili M, Errihani H, Droz JP, Flechon A: Outcome of recurrent and metastatic small cell carcinoma of the bladder. BMC Urol 2009, 9:4.

35. Mackey JR, Au HJ, Hugh J, Venner P: Genitourinary small cell carcinoma: determination of clinical and therapeutic factors associated with survival. J Urol 1998, 159:1624-1629.

36. Ismaili N, Amzerin M, Elmajjaoui S, Droz JP, Flechon A, Errihani H: The role of chemotherapy in the management of bladder cancer. Prog Urol 2011 21(6):369-82.

37. Ismaili N, Elmajjaoui S, Bensouda Y, Belbaraka R, Abahssain H, Allam W, Fadoukhair Z, Mesmoudi M, Tanz R, Mahfoud T, Elomrani A, Khouchani M, Sbitti Y, Benjaafar N, Errihani H, Tahri A: Neoadjuvant or adjuvant chemotherapy: what is the best treatment of muscle invasive bladder cancer? Oncol Rev 2011, 5(3):185-189.

38. Black PC, Brown GA, Dinney CP: The impact of variant histology on the outcome of bladder cancer treated with curative intent. Urol Oncol 2009, 27(1):3-7.

39. Pan CX, Zhang H, Lara PN Jr, Cheng L: Small-cell carcinoma of the urinary bladder: diagnosis and management. Expert Rev Anticancer Ther 2006, 6(12):1707-13.

40. Bex A, Sonke GS, Pos FJ, Brandsma D, Kerst JM, Horenblas S: Symptomatic brain metastases from small-cell carcinoma of the urinary bladder: The Netherlands Cancer Institute experience and literature review. Ann Oncol 2010, 21(11):2240-5.

41. June RR, Dougherty DW, Reese CT, Harpster LE, Hoffman SL, Drabick JJ: Significant activity of single agent vinorelbine against small-cell cancer of the bladder as second line chemotherapy: A case series and review of the literature. Urol Oncol 2010

42. Puglisi M, Dolly S, Faria A, Myerson JS, Popat S, O'Brien ME: Treatment options for small cell lung cancer - do we have more choice? $\mathrm{Br} J$ Cancer 2010, 102(4):629-38.

43. Ismaili N, Arifi S, Flechon A, El Mesbahi O, Blay JY, Droz JP, Errihani H: Small cell cancer of the bladder: pathology, diagnosis, treatment and prognosis. Bull Cancer 2009, 96(6):E30-44.

44. Pant-Purohit M, Lopez-Beltran A, Montironi R, MacLennan GT, Cheng L: Small cell carcinoma of the urinary bladder. Histol Histopathol 2010, 25(2):217-21

45. Wang X, MacLennan GT, Lopez-Beltran A, Cheng L: Small cell carcinoma of the urinary bladder-histogenesis, genetics, diagnosis, biomarkers, treatment, and prognosis. Appl Immunohistochem Mol Morphol 2007, 15(1):8-18.

doi:10.1186/1750-1172-6-75

Cite this article as: Ismaili: A rare bladder cancer - small cell carcinoma:

review and update. Orphanet Journal of Rare Diseases 2011 6:75.

\section{Submit your next manuscript to BioMed Central and take full advantage of:}

- Convenient online submission

- Thorough peer review

- No space constraints or color figure charges

- Immediate publication on acceptance

- Inclusion in PubMed, CAS, Scopus and Google Scholar

- Research which is freely available for redistribution

Submit your manuscript at www.biomedcentral.com/submit
C Biomed Central 